\title{
PENINGKATAN PENGAWASAN GURU AGAMA HINDU DALAM MENGHADAPI PROBLEMATIKA PENDIDIKAN DI KEMENTERIAN AGAMA KOTA DENPASAR
}

\author{
Oleh : \\ Ni Wayan Sukerti \\ (Guru Agama Hindu SD 1 Batubulan)
}

\begin{abstract}
Abstrak
Hambatan yang muncul dalam pelaksanaan program pengawas Pendidikan Agama Hindu adalah salah satu kendala di bidang pendidikan terutama dalam Pendidikan Agama Hindu, sehingga perlu adanya upava yang dilakukan oleh Pengawas Pendidikan Agama Hindu untuk mengatasi kendala tersebut. Unaya mengatasi kendala di bidang pendidikan adalah suatu keharusan untuk selalu dilaksanakan agar kualitas pendidikan dapat ditingkatkan, dikembangkan. Unava oleh pengawas untuk mengatasi hambatan untuk pelaksanaan program pengawasan mengarah pada proses konstruksi. Pengawas Pendidikan Agama Hindu akan berusaha membangun. memberi semangat kepada guru dan dirinva sendiri untuk melaksanakan tugas dengan baik sehingga dapat meningkatkan kinerjanxa.

Kata kunci i Peningkatan Pengawasan Guru terhadap Agama Hindu, Masalah Pendidikan.
\end{abstract}

\begin{abstract}
The obstacles that arise in the implementation of the Hindu Religious Education supervisor program is one of the obstacles in the field of education, especially in Hindu Religious Education, so the need for efforts made by the Superintendent of Hindu Religious Education to overcome these obstacles. Efforts to overcome obstacles in the field of education is a necessity to always be implemented so that the quality of education can be improved, developed and developed. Efforts by supervisors to overcome obstacles to supervisory program implementation lead to the construction process. Supervisors of Hindu Religious Education will try to build, give encouragement to the teacher and himself to carry out the task well, so as to improve its performance.

Keywords : Improved Teacher Supervision of Hinduism, Education Problematics.
\end{abstract}

\section{PENDAHULUAN}

Pelaksanaan pendidikan terutama pendidikan Agama Hindu masih banyak mengalami kendala-kendala. Salah satunya dari lingkungan pendidik atau guru. Guru merupakan salah satu komponen penting dalam proses pembelajaran. Guru sebagai salah satu anggota organisasi sekolah harus dikelola dengan manajemen yang baik. Kinerja guru dalam upaya peningkatan mutu pendidikan, sangat dipengaruhi pula dukungan sarana dan prasarana seperti : 1) buku pelajaran, 2) media pembelajaran, 3) gedung sekolah, 4) alat tulis dan sebagainya. Sampai saat ini buku-buku pelajaran pendidikan Agama Hindu belum dapat dipenuhi secara maksimal oleh pemerintah bahkan buku-buku pelajaran Agama Hindu sering berubah-ubah. Hal ini belum dicermati oleh guru-guru pendidikan Agama Hindu, sehingga proses pembelajaran banyak yang tidak sesuai dengan harapan 
kurikulum.

Hambatan yang timbul dalam pelaksanaan program pengawas Pendidikan Agama Hindu merupakan salah satu hambatan di bidang pendidikan khususnya dalam Pendidikan Agama Hindu, sehingga perlu adanya upaya yang dilakukan Pengawas Pendidikan Agama Hindu untuk mengatasi hambatan tersebut. Upaya mengatasi hambatan pelaksanaan dibidang pendidikan merupakan suatu keharusan untuk selalu dilaksanakan agar mutu pendidikan dapat meningkat, maju dan berkembang. Upaya yang dilakukan pengawas untuk mengatasi hambatan pelaksanaan program pengawas mengarah pada proses konstruksi. Pengawas Pendidikan Agama Hindu akan berusaha membangun, memberikan dorongan kepada guru maupun dirinya agar melaksanakan tugas dengan baik, sehingga dapat meningkatkan kinerjanya.Perilaku guru juga tidak terlepas dari kinerja yang dimiliki oleh guru tersebut. Tampaknya ada dua kecendrungan guru dalam menjalankan tugasnya yaitu pertama ada guru yang pertama-tama memikirkan mengenai penghasilan/ gaji, memandang pekerjaannya sebagai sarana untuk mendapatkan uang, dan sekolah merupakan organisasi yang menjamin kesejahteraan guru. Dengan demikian guru berupaya memberikan pelajaran tambahan sebanyak mungkin agar mendapatkan tambahan honor sebagaimana yang diaharapkan, guru juga mengajar di sejumlah sekolah agar mendapatkan penghasilan tambahan. Akibatnya prilaku guru seperti itu, guru tidak sempat mempersiapkan pelajaran dengan baik atau memeriksa tugas satu persatu, guru hanyalah mengajar dengan metode mengajar yang mudah dilakukan baginya tanpa memperhatikan apakah siswa-siswanya dapat mengerti dengan materi pelajaran yang diajarkan. Kedua ada perilaku guru yang menaruh perhatian pada perkembangan siswa berupaya menyumbangkan segala kemampuannya untuk kepentingan siswa, guru berupaya membantu siswa yang mempunyai kemampuan belajar yang rendah. Guru menggunakan berbagai metode mengajar agar siswa dapat mengerti materi pelajaran yang diajarkannya. Guru tersebut mempunyai kreativitas merasa puas apabila siswa berhasil dengan baik.

Perilaku guru yang menyimpang dan memberikan pengaruh terhadap kinerjanya tampaknya dapat dilihat pada isu-isu yang sedang berkembang saat ini bahwa diketahui guru yang lolos sertifikasi dan sudah mendapatkan tunjangan serifikasi malah menunjukkan kinerja yang kurang baik, guru tersebut malas untuk memberikan pembelajaran di kelas, hal ini diketahui setelah adanya pengawas pendidikan berkunjung ke sekolah (Bali Post, 2017).

Kepemimpinan kepala sekolah juga merupakan salah satu yang menentukan kinerja guru. Faktor perilaku kepemimpinan mempengaruhi kinerja bawahannya. Makin efektif kepemimpinan seseorang maka makin tinggi pula kinerja bawahannya atau sebaliknya. Oleh karena seorang kepala sekolah adalah seseorang pemimpin, inovator ataupun seorang supervisor, maka kualitas kepemimpinannya merupakan kunci keberhasilan kinerja bawahan dan bermuara kepada output dan outcome yang berkualitas. Kepemimpinan kepala sekolah merupakan salah satu kekuatan efektif dalam pengelolaan sekolah yang bertanggung jawab dalam menghadapi perubahan dan memperbaiki mutu pendidikan. Mutu pendidikan disuatu lembaga pendidikan dan jenjang pen- 
didikan sangat tergantung kepada pemimpin sekolah. Ini berarti kepala sekolah sebagai pemimpin di suatu sekolah, pola kepemimpinannya sangat mempengaruhi dan menentukan kinerja bawahannya terutama kinerja guru. Oleh karena itu, untuk peningkatan kinerja guru pemimpin harus memperbaiki perilaku kepemimpinannya, menyesuaikan gaya kepemimpinannya dengan situasi yang ada yaitu kemampuan dan kemauan guru, sehingga guru mau meningkatkan kinerjanya dan selalu ingin mencapai hasil yang lebih baik dari sebelumnya.

\section{PEMBAHASAN}

Beberapa hambatan yang dihadapi oleh Para Pengawas Pendidikan Agama Hindu di Kementerian Agama Kota Denpasar dapat dilihat dari faktor kualifikasi dan pengalaman kerja pengawas yang tidak berlatar belakang Pendidikan Agama Hindu, faktor sarana kerja Pengawas Pendididkan Agama Hindu tidak memadai, faktor dari kondisi Guru Pendidikan Agama Hindu, serta faktor kebijakan dari atasan, sehingga selanjutnya dapat diuraikan upaya yang dilakukan para Pengawas Pendidikan Agama Hindu dalam mengatasi faktor penghambat tersebut sebagai berikut.

\section{Upaya Mengatasi Faktor Ham- batan Kualifikasi dan Pengala- man Kerja Pengawas yang Tidak Berlatar Belakang Pendidikan Agama Hindu}

Faktor penghambat yang dikarenakan adanya Pengawas Pendidikan Agama Hindu yang tidak memiliki kualifikasi dan pengalaman kerja dibidang Pendidikan Agama Hindu memang hambatan yang muncul pada awal seorang pengawas yang tidak memiliki kualifikasi dan pengalaman kerja dibidang Pendidikan Agama Hindu dalam melakukan pengawasan. Hal ini terjadi karena proses penunjukan para calon pengawas yang menjadi tanggung jawab Pejabat dalam wilayah Kementerian Agama Kota Denpasar, walaupun demikian para Pengawas Pendidikan Agama Hindu di Kementerian Agama Kota Denpasar selalu berupaya untuk tetap meningkatkan profesionalismenya dengan melakukan Kegiatan Peningkatan Profesionalisme Pengawas yang merupakan salah satu program tahunan dan semester para Pengawas Pendidikan Agama Hindu di Kementerian Agama Kota Denpasar. Berdasarkan data yang didapat di lapangan menunjukkan bahwa Kementerian Agama Provinsi Bali memang sudah mengadakan orientasi dan diklat sehubungan dengan peningkatan Profesionalisme Pengawas, begitu oleh Kantor Kementerian Agama Kota Denpasar juga secara melaksanakan kegiatan tersebut demi peningkatan profesionalisme para Pengawas Pendidikan Agama Hindu di Kementerian Agama Kota Denpasar dengan mengundang narasumber untuk melaksanakan orientasi dan diklat terkait dengan Pengawasan Pendidikan Agama Hindu.

Terkait dengan profesionalisme Pengawas Pendidikan Agama Hindu, dalam Peraturan Menteri Agama Republik Indonesia No. 16 tahun 2010 tentang Pengelolaan Pendidikan Agama pada Sekolah pasal 21 disebutkan bahwa Pengawas Pendidikan Agama harus memiliki 6 kompetensi meliputi, kompetensi kepribadian, supervisi manajerial, supervisi akademik, evaluasi pendidikan, penelitian pengembangan, dan sosial.

Berdasarkan uraian di atas tampaknya dalam pelaksanaan tugas seorang Pengawas Pendidikan Agama 
Hindu tidaklah mudah terlebih lagi bagi Pengawas Pendidikan Agama Hindu yang tidak memiliki kualifikasi dan pengalaman kerja dibidang Pendidikan Agama Hindu. Para pengawas tersebut dituntut untuk memahami tugasnya melalui pelaksanaan kerja maupun melalui Kegiatan Peningkatan Profesionalisme Pengawas baik melalui orientasi maupun diklat, dengan demikian untuk selanjutnya memiliki kemampuan yang sama dengan Pengawas yang memiliki kualifikasi dan pengalaman kerja dibidang Pendidikan Agama Hindu, yang pada akhirnya tentu berpengaruh juga terhadap peningkatan kinerja Guru Agama Hindu yang dibinanya.

\section{Upaya Mengatasi Faktor Ham- batan Sarana Kerja Pengawas Pendidikan Agama Hindu}

Pengawas Pendidikan Agama Hindu dalam mengatasi hambatan berkenaan dengan sarana kerja yang tidak memadai; seperti kurangnya fasilitas kendaraan dinas dan komputer selalu berupaya untuk mengajukan permohonan pengadaan fasilitas kendaraan dan komputer ke pusat atas persetujuan Kepala Kantor Kementerian Agama Kota Denpasar untuk memperlancar pelaksanaan program kerja Pengawas Pendidikan Agama Hindu. Sementara menunggu respon dalam pengadaan fasilitas kendaraan dan komputer yang diusulkan, Pengawas Pendidikan Agama Hindu selalu mengupayakan agar tugas dan kewajibannya tetap terlaksana dengan fasilitas yang dimiliki saat ini.

Berdasarkan observasi dan hasil wawancara di lapangan ditemukan bahwa pengawas Pendidikan Agama Hindu yang belum mendapatkan kendaraan menggunakan kendaraan pribadi untuk melaksanakan tugas, be- gitu pula untuk menyelesaikan Laporan Pengawas, Pengawas Pendidikan Agama Hindu memanfaatkan komputer pribadi atau menggunakan jasa pengetikan untuk membantu penyelesaian tugas dan kewajibannya.

Pengawas Pendidikan Agama Hindu di Kementerian Agama Kota Denpasar memiliki rasa tanggung jawab yang besar untuk menyelesaikan tugasnya. Dalam Bhagavad Gita, II.47 disebutkan:

karmany evadhikāras te mā phaleśu kadācana, mā te sańgo 'stv akarmani (Bhavadgita II, 47)

Terjemahan :
Berbuatlah hanya demi kewajibanmu, bukan hasil perbuatan itu (yang kau pikirkan), jangan sekali kali jadi motifmu da- lam bekerja, jangan pula berdiam diri tanpa bekerja.

Berdasarkan uraian di atas memang sudah sepatutnya sebagai manusia harus melaksanakan tugas dan kewajiban dengan baik. Kutipan sloka di atas memberikan pengertian bahwa dalam melaksanakan suatu kewajiban janganlah hanya memikirkan hasil yang didapat. Melaksanakan suatu kewajiban hendaknya didasari dengan ketulusiklasan tanpa terikat dengan hasil yang didapat, sehingga dalam pelaksanaan tugas dan kewajiban timbul rasa tanggung jawab yang besar. Hal ini tampaknya terlihat pada para Pengawas Pendidikan Agama Hindu di Kementerian Agama Kota Denpasar, dengan selalu berusaha setiap tahunnya untuk mengajukan permohonan pengadaan fasilitas kendaraan dinas dan komputer sebagai penunjang pelaksanaan program kerja pengawas, 
dan sementara menunggu respon dari pusat untuk pengadaan fasilitas kendaraan dinas dan komputer, para Pengawas Pendidikan Agama Hindu tidak berdiam diri hanya menunggu dan memikirkan kapan fasilitas tersebut akan datang.

Dengan sarana seadanya yang dimiliki, para Pengawas Pendidikan Agama Hindu tetap melaksanakan tugas dan kewajibannya menjalankan program kerja dengan penuh rasa tanggung jawab, walaupun hasilnya tidak sempurna sekali. Dengan demikian hal ini akan memberikan contoh baik kepada Guru Pendidikan Agama Hindu yang dibina oleh para Pengawas Pendidikan Agama Hindu, sehingga berpengaruh positif pada peningkatan kinerja Guru Pendidikan Agama Hindu di kawasan Kota Denpasar.

\section{Upaya Mengatasi Faktor Peng- hambat Berkenaan dengan Kon- disi Guru Pendidikan Agama Hindu}

Kondisi Guru Pendidikan Agama Hindu tingkat Sekolah Menengah Pertama di kawasan Kota Denpasar memiliki potensi dan wawasan yang tidak sama serta masih kurangnya penguasaan di bidang teknologi. Potensi dan wawasan guru yang tidak sama dimaksud dalam hal ini disebabkan karena kualifikasi, kompetensi, serta pengalaman atau masa kerja guru yang berbeda-beda, sehingga pengetahuan guru mengenai kelengkapan pembelajarannya seperti program pembelajaran, rencana pelaksanaan pembelajaran dan silabus pun tidak sama. Inilah yang menyebabkan para Pengawas Pendidikan Agama Hindu sulit untuk memberikan pemahaman mengenai pelaksanaan program kerja Pengawas Pendidikan Agama Hindu kepada
Guru Pendidikan Agama Hindu yang dibinanya. Upaya yang dilakukan para Pengawas Pendidikan Agama Hindu untuk mengatasi hal tersebut adalah dengan selalu mengadakan pembinaan yang intensif untuk Guru Pendidikan Agama Hindu di Kawasan Kota Denpasar.

Pembinaan untuk Guru Pendidikan Agama Hindu di kawasan Kota Denpasar dilakukan oleh Pengawas Pendidikan Agama Hindu dengan memberikan pembinaan secara individual maupun secara kelompok. Mengenai pembinaan secara individual berdasarkan hasil observasi dan wawancara didapatkan bahwa pembinaan secara individual biasanya dilakukan pada saat Pengawas Pendidikan Agama Hindu melakukan kunjungan ke sekolah-sekolah binaannya dengan bertemu langsung Guru Pendidikan Agama Hindu di sekolah yang dikunjungi. Kegiatan kunjungan ke sekolah binaan ini merupakan kesempatan untuk memberikan pembinaan terkait dengan kinerja guru khususnya Guru Pendidikan Agama Hindu.

Pembinaan secara individual yang dilakukan Pengawas Pendidikan Agama Hindu pada saat melakukan kunjungan ke sekolah-sekolah tampaknya sangat efektif, Pengawas Pendidikan Agama Hindu yang melakukan kunjungan ke sekolah dapat memonitoring langsung kinerja Guru Pendidikan Agama Hindu, sehingga pengawas mengetahui langsung kelemahan dan kekurangan Guru Pendidikan Agama Hindu baik terkait dengan proses belajar mengajar di kelas maupun kelengkapan administrasi guru. Dalam hal inilah Pengawas Pendidikan Agama Hindu menerapkan Supervisi Klinis, mencari sebab-sebab atau kelemahan yang terjadi, kemudian secara langsung pula diusahakan bagaimana cara memperbaiki kelemahan atau 
kekurangan yang ditemui Pengawas Pendidikan Agama Hindu dengan memberikan pembinaan langsung kepada Guru Pendidikan Agama Hindu di sekolah yang dikunjunginya.

Terkait dengan pembinaan secara kelompok berdasarkan hasil wawancara dan observasi di lapangan ditemukan bahwa pembinaan secara kelompok dilakukan pada saat Guru Pendidikan Agama Hindu melakukan KKG Agama yang biasanya diadakan setiap tri wulan sekali diikuti oleh Guru Pendidikan Agama Hindu tingkat SMP se kecamatan atau KKG Agama yang dibentuk Gugus SMP setiap sebulan sekali. Pengawas Pendidikan Agama Hindu biasanya hadir sesuai dengan wilayah yang dibinanya. Kegiatan ini dipakai kesempatan oleh Para Pengawas Pendidikan Agama Hindu untuk memberikan pembinaan kepada Guru Pendidikan Agama Hindu.

Wahyudin (1995:10), KKG merupakan wadah dalam pembinaan profesional guru yang dapat dimanfaatkan untuk berkomunikasi, bertukar fikiran dan berbagi pengalaman, melaksanakan berbagai demonstrasi, atraksi dan simulasi dalam pembelajaran. Mengacu pada uraian di atas memberikan pengertian bahwa KKG Agama Hindu adalah sebuah forum atau perkumpulan guruguru mata pelajaran Pendidikan Agama Hindu yang mempunyai kegiatan khusus memberikan informasiinformasi pendidikan dalam rangka meningkatkan kualitas pribadi guru dalam proses belajar mengajar. Kegiatan KKG Agama Hindu tersebut merupakan moment yang tepat bagi Pengawas Pendidikan Agama Hindu melakukan pembinaan untuk peningkatan kinerja Guru Pendidikan Agama Hindu. Pada kegiatan ini Guru Pendidikan Agama Hindu saling sharing mengenai masalah dan kesulitan rencana pelaksana pengajaran yang dihadapi, serta diskusi mengenai pembahasan pembuatan silabus dan RPP, dengan demikian para Pengawas Pendidikan Agama Hindu mengetahui kesulitan apa yang dihadapi oleh Guru Pendidikan Agama Hindu dalam pelaksanaan tugasnya dan dapat memberikan saran atau solusi untuk membantu Guru Pendidikan Agama Hindu yang dibinanya.

Pengawas Pendidikan Agama Hindu berupaya membangun pengetahuan Guru Pendidikan Agama Hindu sehingga dapat meningkatkan kinerjanya. Piaget dalam Dahar (1989 : 159) menegaskan bahwa pengetahuan tersebut dibangun dalam pikiran melalui asimilasi dan akomodasi. Asimilasi adalah penyerapan informasi baru dalam pikiran, sedangkan akomodasi adalah menyusun kembali struktur pikiran karena adanya informasi baru, sehingga informasi tersebut mempunyai tempat.

Berdasarkan uraian di atas Pengawas Pendidikan Agama Hindu dalam kegiatan KKG Agama Hindu selalu membangun pengetahuan Guru Pendidikan Agama Hindu dengan memberikan pembinaan dan informasi -informasi baru terkait dengan peningkatan Kinerja Guru Pendidikan Agama Hindu. Dengan adanya pembinaan dan informasi-informasi baru tersebut Guru Pendidikan Agama Hindu merasa terbangun motivasinya untuk meningkatkan kinerjanya sebagai Guru Pendidikan Agama Hindu.

\section{Upaya Mengatasi Faktor Peng- hambat Berkenaan dengan Ke- bijakan}

Penyusunan Laporan Pengawas Pendidikan Agama Hindu yang belum memiliki kebijakan yang pasti dari atasan menjadikan para Pengawas Pen- 
didikan Agama Hindu merasa kesulitan dalam penyusunannya. Laporan Pengawas merupakan hal yang penting bagi Para Pengawas Pendidikan Agama Hindu karena laporan pengawas adalah media yang digunakan Pengawas Pendidikan Agama Hindu di Kementerian Agama Kota Denpasar untuk mengkomunikasikan pemberitahuan hasil pengawasan, monitoring dan evaluasi kepada atasannya. Terkait dengan upaya yang dilakukan para Pengawas Pendidikan Agama Hindu di Kementerian Agama Kota Denpasar untuk mengatasi hal tersebut, berdasarkan hasil wawancara dan observasi di lapangan ditemukan bahwa dua bulan sebelum penyusunan Laporan Pengawas, para Pengawas Pendidikan Agama Hindu di Kementerian Agama Kota Denpasar secara intern mengadakan rapat untuk membahas bagaimana penyusunan Laporan Pengawas Pendidikan Agama Hindu. Hal ini dilakukan agar antara Pengawas Pendidikan Agama Hindu memiliki kesepakatan dan keseragaman dalam penyusunan Laporan Pengawas Pendidikan Agama Hindu di Kementerian Agama kota Denpasar.

Melaksanakan rapat sebelum penyusunan Laporan Pengawas menjadi cara Pengawas Pendidikan Agama Hindu di Kementerian Agama Kota Denpasar untuk mendapatkan kesepakatan dalam Penyusunan Laporan Pengawas yang nantinya akan disetor ke atasan.

Rapat adalah pertemuan para anggota organisasi/para pegawai baik swasta maupun pemerintah yang bertujuan untuk memberikan penjelasan kepada para anggota, tentang kebijaksanaan yang diambil oleh pimpinan organisasi, tentang prosedur kerja dan tata cara kerja baru, untuk mendapatkan keseragaman kerja" (Wursanto, 1987:136).
Belum adanya pedoman yang pasti terkait dengan penyusunan Laporan Pengawas Pendidikan Agama Hindu, mengharuskan para Pengawas Pendidikan Agama Hindu di Kementerian Agama Kota Denpasar mengadakan rapat intern untuk mendapatkan kesepakatan mengenai prosedur penyusunan Laporan Pengawas. Rapat sebelum penyusunan Laporan Pengawas Pendidikan Agama Hindu dirasakan sangat penting guna mendapatkan keseragaman untuk pembuatan Laporan Pengawas Pendidikan Agama Hindu, dengan keseragaman tersebut dapat dilihat kekompakan yang ditunjukan oleh Pengawas Pendidikan Agama Hindu, sehingga dapat dijadikan panutan bagi Guru Pendidikan Agama Hindu untuk peningkatan kinerjanya.

\section{PENUTUP}

Kepemimpinan pengawas terhadap guru merupakan salah satu yang menentukan kinerja guru. Faktor perilaku kepemimpinan mempengaruhi kinerja bawahannya. Makin efektif kepemimpinan seseorang maka makin tinggi pula kinerja bawahannya atau sebaliknya. Oleh karenanya pengawas adalah seseorang pemimpin, inovator ataupun seorang supervisor, maka kualitas kepemimpinannya merupakan kunci keberhasilan kinerja bawahan dan bermuara kepada output dan outcome yang berkualitas. Kepemimpinan pengawas guru merupakan salah satu kekuatan efektif dalam pengelolaan pendidikan yang bertanggung jawab dalam menghadapi perubahan dan memperbaiki mutu pendidikan. Mutu pendidikan disuatu lembaga pendidikan dan jenjang pendidikan sangat tergantung kepada pemimpin sekolah. Ini berarti pemimpin sekolah dalam hal 
ini sebagai pemimpin terhadap kinerja guru, pola kepemimpinannya sangat mempengaruhi dan menentukan kinerja bawahannya terutama kinerja guru.

\section{DAFTAR PUSTAKA}

Elsbree, Willand S., Harold J. Mc. Nally and Richard Wyne, 1987. Elementary School Administration and Supervision, Third Edition, New York: American Book Company.

Dahar, R.W. 1989. Teori-Teori Belajar. Jakarta: Erlangga.

Darma, Agus. 1985. Manajemen Prestasi Kerja. Jakarta: PT Rajawali Press.

Departemen Pendidikan dan Nasional. 2008. Kamus Besar Bahasa Indonesia. Jakarta: PT Gramedia Pustaka Utama.

Departemen Pendidikan dan Nasional. 2010. Penyusunan Program Pengawasan Sekolah. Jakarta: Direktorat Jenderal Peningkatan Mutu Pendidik dan Tenaga Kependidikan.

Departemen Pendidikan dan Nasional. 2007. Peraturan Menteri Pendidikan Nasional Republik Indonesia Nomor 12 Tahun 2007 Tentang Standar Pengawas Sekolah/Madrasah. Jakarta: Direktorat Jenderal Peningkatan Mutu Pendidik dan Tenaga Kependidikan.

Nurkolis. 2003. Manajemen Berbasis Sekolah. Jakarta: Grasindo.

Ormston, M dan Shaw, M. 1994. Inspection: Preparation Guide for School. London: Logman Group.

Pudja, G. 2005. Bhagawad Gita (Pancama Veda). Surabaya: Paramita

Rahman, Arief. 2006. Guru Powerful, Guru Masa Depan, Jakarta: Rineka Cipta.

Wahab, Solichin Abdul. 1991. Analisa
Kebijakan: Dari Formulasi ke Implementation. Jakarta: PT. Bumi Aksara.

Wahjosumidjo, 2003, Kepemimpinan Kepala Sekolah. Jakarta: PT Raja Grafindo Persada.

Wahyudin, Din. 1995. Monitoring dan Evaluasi Petunjuk bagi Para

Pelaksana. Jakarta: PEQIP. 